\title{
THE ASSOCIATION BETWEEN COMPLICATIONS IN PATIENTS DURING THE ANESTHETIC RECOVERY PERIOD AND THE PHYSIOLOGICAL CONDITIONS EXPERIENCED IN THE PREOPERATIVE PERIOD
}

\author{
ASSOCIAÇÃO DAS COMPLICAÇÕES EM PACIENTES NO PERÍODO DE \\ RECUPERAÇÃO ANESTÉSICA COM AS CONDIÇÕES FISIOLÓGICAS DO \\ PERÍODO PRÉ-OPERATÓRIO
}

\author{
Fiama Chagas NUNES ${ }^{1}$; Adelaide De Mattia ROCHA ${ }^{2}$; Ana Lúcia D MATTIA ${ }^{3}$ \\ 1. Enfermeira, Mestranda em Enfermagem da Escola de Enfermagem da Universidade Federal de Minas Gerais - UFMG, Belo \\ Horizonte, MG, Brasil. fiamacn@yahoo.com.br; 2. Doutora em Enfermagem, Professora Associada da Escola de Enfermagem da \\ UFMG, Belo Horizonte, MG, Brasil. adelaidedemattia@gmail.com; 3. Doutora em Enfermagem, Professora Adjunta da Escola de \\ Enfermagem da UFMG, Belo Horizonte, MG, Brasil.
}

\begin{abstract}
The aim of this research is to verify the correlation between the patient's underlying diseases in the preoperative period and the occurrence of complications during the anesthetic recovery period. This is a quantitative field research, with a non-experimental design, comparative, and prospective. The sample is part of a big study conducted with 42 patients. For this research was selected 24 patients, who were submitted to elective surgery, under general anesthesia, with the American Society Anesthesiologists (ASA) status classification I or II; also they should be healthy and do not have any of the comorbidities listed as a criteria of exclusion from the study. The most common complications found were pain, hypoxia, hypothermia, and changes level of consciousness. Comparing this result with the results obtained with the initial study (conducted with 42 patients), regardless of whether the patient has or not comorbidities or mild diseases, which led them to the surgical procedure, the triad of complications, composed of pain, hypoxemia and hypothermia were the most frequent during the first 60 minutes of patient permanence in the PACU. In the manual analysis of the questionnaires, it was not verified significant agreement between the most common clinical manifestations and the presence of comorbidities. It is recommended that further studies should be conducted in order to properly address the complications presented by patients without comorbidities, when in the anesthetic recovery period.
\end{abstract}

KEYWORDS: Perioperative Nursing. Preoperative Period. Recovery Room. Postoperative Complications.

\section{INTRODUCTION}

The anesthetic recovery period comprises the time between the patient discharge from the operating room (OR) until the discharge from the post-anesthesia care unit (PACU). (MORAES; PENICHE, 2003).

The PACU is an area, designed to take care of patients coming from the immediate postoperative period. It ought to have a multidisciplinary team designed to provide the health care until the patient has the cardiorespiratory stability and state of consciousness stable. (POPOV; PENICHE, 2009).

The care provided in the PACU must correspond with the routines of clinical and instrumental monitoring; therefore, it should consider any signs or symptoms that the patient presents. (OLIVEIRA FILHO, 2003).

During the anesthetic recovery period, the patient may present several complications that could be associated to the preoperative clinical condition, to the anesthetic-surgical procedure, or the efficacy of the therapeutic methods implemented.
(MORAES; PENICHE, 2003; GALDEANO; ROSSI; PENICHE, 2007; POPOV; PENICHE, 2009).

The alterations verified in the patients who are in anesthetic recovery period can endanger the human body systems, such as the respiratory system, the cardiovascular system, the nervous system (thermoregulation), the integumentary system, the musculoskeletal system, the urinary system, the digestive system, the immune system, and the emotional state. (BRASIL, 1994; MORAES; PENICHE, 2003; NUNES; MATOS; DE MATTIA, 2014).

Hence, there are concerns about the quality of nursing toward surgical patients not maintaining a consistent standard or being provided in an individualized manner as it should be.

However, the majority of the studies with patients in anesthetic recovery period have been conducted with patients who have American Society Anesthesiologists (ASA) status classification II and some systemic alteration that does not require surgical procedure, but can interfere with the 
clinical condition presented by the patient in the PACU.

Considering the high incidence of complications that occur with the patients during the anesthetic recovery period, it brings up the question: What is the relationship between the occurrence of complications in patients healthy and patients with some mild physiological problem?

Therefore, this study aims to verify the correlation between the patient physiologic conditions in the perioperative period and the occurrence of complications during the anesthetic recovery period.

\section{METHODOLOGY}

The research was used a quantitative approach, with a non-experimental design, comparative, field, and prospective. It was conducted in a big federal public hospital, located in the state of Minas Gerais. The research field was the PACU. It had eight beds, which maintained the room temperature of $22^{\circ}$ to $24^{\circ}$ degrees Celsius, with relative humidity between $25 \%$ and $60 \%$, according to the recommendations established by Brazil's Ministry of Health.

This study is part of a research project developed in 2013 and 2014. In compliance with the requirements established by Resolution 466/2012 of the National Health Council, it received the approval by the Research Ethics Committee at Federal University of Minas Gerais (CEP UFMG) under the protocol numbers CEP UFMG 274.655 and CASE 14887213.4.0000.5149.

The data was collected between December 2013 and March 2014. The Informed Consent Form (ICF) was signed by all of the participants after they received the background of the study and its objectives as well as further explanations from the investigator. The clarification about the purpose of this research and signature of the ICF were received in the patient room, during the postoperative period.

To gather a consensus about the sample size, the study considered the numbers of independent variables originally proposed and utilized around 10 to 11 patients for each variable used. (NUNES; MATOS; DE MATTIA, 2014). The independent variables were: age (adults between 18 - 60 years old), the surgical moment (elective surgeries), the type of anesthesia (general anesthesia), and the American Society Anesthesiologists (ASA) status classification I or II, totalizing an amount of 42 participants.
Trying to elucidate the objectives of this research were 24 sleeted patients from the sample utilized in the first study.

The following was considered as inclusion criteria for this research: adult patients, who signed the ICF, aged 18 - 60 years old, submitted to elective surgery, under general anesthesia, with ASA status classification I or II, and healthy or with mild physiological problem that led to the surgical procedure.

The exclusion criteria for participation in the study were patients younger than 18 years old or older than 60 years old, submitted to emergency or urgent surgery, under local anesthesia, with ASA status classification III or VI. Patients with the diagnosis of the following comorbidities: lung diseases, cardiovascular diseases, endocrine dysfunction, kidney disease or urinary tract, gastrointestinal allergies or dysfunctions. Smokers and drinkers were also excluded from the study.

To perform the data collection was elaborated a semi-structured questionnaire, which included the following information: characteristics of the patient, characterization of the anesthetic and surgical procedure, and the complications presented by the patient during the anesthetic period recovery.

The variables used to characterization of the sample were: gender, age, ASA status classification, and preexisting medical comorbidities. The type of surgery and anesthesia, and the time of duration the procedure were used to characterize the anestheticsurgical procedure.

To identify and analyze the complications presented by the patients was utilized the Aldrete Kroulik index, in order to assess the patient's muscle activity, breathing, circulation, consciousness, and oxygen saturation $\left(\mathrm{SpO}_{2}\right)$.

The Aldrete - Kroulik score ranges between zero (0) and two (2) for each parameter, in which zero (0) indicates conditions of great severity, one (1) corresponds to an intermediate level, and two (2) represents restored functions. (CASTRO et al., 2012).

According to the Aldrete - Kroulik index, the muscle activity is classified as score two (2) when the patient is able to move the four limbs, one (1) when the patient can move two limb, and zero (0) when the patient is unable to move any of limbs voluntarily or on command. This parameter was used to evaluate the presence of movement dysfunction.

The breathing is evaluated as score two (2) when the patient can breathe deeply and cough, score one (1) on dyspnea or limited breathing capacity, and zero (0) on apnea. (SOBECC, 2013). 
This parameter was utilized to analyze respiratory dysfunction, such as dyspnea, hypopnea, and hyperpnea.

The circulation is evaluated by the measurements of the systolic blood pressure. It compares the pressure levels at the preoperative moment with the postoperative moment. The score two (2) is when the post-anesthetic blood pressure has up to $20 \%$ of difference from the preanesthetic, the score one (1) when the blood pressure has $20 \%$ to $49 \%$ of difference between postanesthetic and preanesthetic period, and zero (0) when the blood pressure presents a difference of $50 \%$ or higher comparing to the preanesthetic period. This parameter is used to evaluate the blood pressure complications, such as hypotension and hypertension.

The consciousness is evaluated as score two (2) when the patient is lucid and oriented to time and place, score one (1) whether the patient requires supplemental oxygen to maintain an $\mathrm{SpO} 2>90 \%$, and score zero $(0)$ when the $\mathrm{SpO} 2<90 \%$ even with supplemental oxygen. (SOBECC, 2013). This parameter determined the oxygenation complication, such as hypoxemia.

The application of the Aldrete - Kroulik index in the PACU is indicated to whenever the patient arrives in the PACU at minute zero, every 15 minutes during the first hour, every 30 minutes during the second hour, and every one hour from the third hour of permanence at the PACU. Thus, the scores are measured at zero (0), 15, 30, 45, 60, 90, 120, and 180 minutes. (SOBECC, 2013).

The data collected about vital signs were: blood pressure (BP), heart rate (HR), respiratory rate (RR), and axillary body temperature (T).

For analyzing blood pressure, it was considered to be arterial hypotension when the systolic blood pressure was less than $20 \%$ from the blood pressure during the preanesthetic period, and hypertension when it was more than $20 \%$ from the preanesthetic period. (SOBECC, 2013).

For analyzing the HR, it was considered to be bradycardia when the HR was under than 60 beats per minute (BPM), and tachycardia when the HR was more than $100 \mathrm{BPM}$.

For the temperature, it was considered hypothermia when the body core temperature was below than $36^{\circ} \mathrm{C}$ and hyperthermia when the body temperature was above than $37.8^{\circ} \mathrm{C}$. (POTTER; PERRY, 2005).

The RR was considered normal for adults when they had a respiration rate of 12 to 22 breaths per minute (BARROS, 2010).
Pain and nausea were analyzed by the verbal reporting from the patient and the vomit by the presence or absence of it.

The data was collected at admission of the patient in the PACU, considering zero (0) minutes when the patient arrived at the PACU, then consecutively gathered every 15 minutes for 60 minutes.

To characterize the type of surgery was considered the medical specialty nomenclature, which is utilized by the professionals who work at the hospital where the data was collected.

The statistical analysis was performed with the Statistical Package for the Social Sciences (SPSS), version 14.0. The categorical variables were presented with relative and absolute frequency, and the continuous variables were described with minimum and maximum values, mean, and standard deviation.

\section{RESULTS}

The results are presented according to the subdivisions of the questionnaire. It addresses the characterization of the patient, anesthetic-surgical procedure, and characterization of the complications displayed by the patient.

\section{Characterization of the patient}

In the first part of the questionnaire was analyzed the following information: gender, age, and ASA status classification.

Regarding to the gender, it had prevalence of women, being $16(66.7 \%)$ female and 8 (33.3\%) male, the mean age was 35.33 years and a standard deviation of (12.2), it means a minimal age of 18 and maximum of 57 years old.

Evaluating the (ASA) Physical Status classification, it had the prevalence of ASA I in 15 $(62.5 \%)$ patients and 9 (37.5\%) patients were classified as ASA II.

\section{Characterization of the anesthetic and surgical procedure}

The second part of the questionnaire evaluated the length of time for the surgical procedure and the anesthesia, as well as the prevalence of types of surgery according to the medical specialty.

The mean of length of time for the surgeries was 189.25 minutes, standard deviation of 90.6, maximum of 480 minutes and minimum of 65 minutes. The anesthesia time was 233.1 minutes, 88.6 of standard deviation, maximum of 530 minutes and minimum of 110 minutes. 
About the surgical specialty, the most frequent was gynecologic surgeries 5 (20.8\%), followed by otorhinolaryngology $4(16.7 \%)$, breast surgeries $3(12.5 \%)$, urologic surgeries $3(12.5 \%)$ plastic surgeries $2(8.3 \%)$, oral and maxillofacial surgeries $2(8.3 \%)$, orthopedic surgeries $2(8.3 \%)$, surgery of the digestive apparatus 1 (4.2\%), neurological $1(4.2 \%)$, and head and neck surgery 1 $(4.2 \%)$.

\section{Characterization of complications presented by the patients}

The complications presented by the patients were analyzed by the values of vital signs, the scores in Aldrete - Kroulik index, and presence or reporting of pain, nausea, and vomit. These parameters were analyzed in the moment when the patient arrived in the PACU, recorded as minute zero (0), and then consecutively every 15 minutes for 60 minutes.

Table 1 refers to the vital sign parameters (BP, HR, RR, and T), which were measured at zero (0), 15, 30, 45, and 60 minutes.

Considering the length of time of permanence in the PACU, the mean BP and HR decreases, and the mean $\mathrm{RR}$ and $\mathrm{T}$ remained broadly constant.

Table 1. Frequency distribution of the vital signs values. Belo Horizonte, 2015.

\begin{tabular}{llll}
\hline \multicolumn{1}{c}{ Vital sign } & Mean $(\mathrm{SD})$ & Minimum & Maximum \\
\hline BP $(\mathrm{mmHg})$ & & & \\
0 & $119.7(17.0)$ & 90 & 164 \\
15 & $115.3(13.4)$ & 89 & 138 \\
30 & $113.9(12.5)$ & 87 & 137 \\
45 & $111.7(15.1)$ & 81 & 141 \\
60 & $113.5(12.6)$ & 90 & \\
HR $(\mathrm{BPM})$ & & & 109 \\
0 & $87.5(14.3)$ & 62 & 127 \\
15 & $89.3(16.8)$ & 61 & 114 \\
30 & $83.6(14.9)$ & 55 & 116 \\
45 & $84.5(14.6)$ & 58 & 112 \\
60 & $83.1(14.4)$ & 57 & 19 \\
$\mathrm{RR}$ & & & 19 \\
0 & $16.1(1.3)$ & 13 & 19 \\
15 & $16.2(1.3)$ & 13 & 19 \\
30 & $16.2(1.3)$ & 13 & 19 \\
45 & $16.2(1.6)$ & 12 & 36.5 \\
60 & $16.3(1.3)$ & 13 & 36.5 \\
$\mathrm{~T}\left({ }^{\circ} \mathrm{C}\right)$ & & & 36.7 \\
0 & $35.2(1.0)$ & 32.7 & 36.7 \\
15 & $35.3(0.8)$ & 33.1 & 36.7 \\
30 & $35.5(0.8)$ & 33.4 & \\
45 & $35.7(0.6)$ & 33.9 & 33.9 \\
60 & $35.7(0.6)$ & & \\
\hline
\end{tabular}

Regarding to the parameters of the Aldrete Kroulik index, which covers the patient's muscle activity, breathing, circulation, consciousness and oxygen saturation $(\mathrm{SpO} 2)$, the patients were analyzed every 15 minutes in the PACU. The scores obtained with the Aldrete - Kroulik index ranged between two (2) and one (1), and no patient had the score zero $(0)$.

Relative to the muscle activity, all the patients obtained score two (2) when they arrived in the PACU, remaining without alterations of this parameter during the 60 minutes of permanence in this room.

In the breathing parameter, $3(12.5 \%)$ patients received score one (1) when they arrived in the PACU, after 15 minutes this number increased to $4(16.7 \%)$ patients. After 30 minutes until the complete time of 60 minutes, $3(12.5 \%)$ patients got score one (1) and $21(87.5 \%)$ got score two (2).

In the circulation parameter, 4 patients (16.7\%) arrived in the PACU with score one (1), 2 (8.3\%) patients got a score one (1) during the evaluation at 15 and 30 minutes, and after 45 
minutes until 60 minutes $3(12.5 \%)$ patients remained with score one (1).

Relative to the consciousness, 10 patients $(41.7 \%)$ arrived drowsy at the PACU and received score one (1), and at the 60-minute mark $2(8.3 \%)$ patients still remained with this score.

Analyzing the $\mathrm{SpO}_{2}, 14$ patients $(58.3 \%)$ arrived in the PACU with score one (1), and at the
60 -minute mark 16 patients $(66.7 \%)$ were with a score two (2).

The table 2 presents the values of the Aldrete - Kroulik index in relation to the length of patient permanence in the PACU. One notable observation is the improvement in the mean scores every 15 minutes of permanence in the PACU.

Table 2. Frequency distribution of the scores in Aldrete - Kroulik index. Belo Horizonte, 2015.

\begin{tabular}{llll}
\hline Time (Minutes) & Mean $(\mathrm{SD})$ IAK & Minimum & Maximum \\
\hline 0 & $8.5(1.2)$ & 6 & 10 \\
15 & $8.8(1.0)$ & 7 & 10 \\
30 & $9.1(0.9)$ & 7 & 10 \\
45 & $9.2(0.9)$ & 7 & 10 \\
60 & $9.3(0.9)$ & 7 & 10 \\
\hline
\end{tabular}

The complications presented by the patients during the anesthetic recovery period were: arterial hypotension and hypertension, bradycardia and tachycardia, hypothermia, bradypnea, anxiety, pain, alteration of consciousness, hypoxemia and changes in breathing (Table 3).

It could be observed in table 3 that the complications most frequent were pain, hypoxemia, hypothermia and alterations of consciousness. Throughout the 60 minutes, the mean for pain was 12.6 patients, the mean for hypoxemia was 11.2 patients, and for hypothermia and alterations of consciousness the mean was 5.2 and 4.8 patients, respectively.

No patient showed movement dysfunction, tachypnea, nausea, vomit, and hyperthermia.
Over the course of 60 minutes of permanence in the PACU, the complications of arterial hypertension, tachycardia, hypothermia, alteration of consciousness, and hypoxemia decreased.

It could be observed that over time, there were an increase of occurrence of arterial hypotension, bradycardia, anxiety, and pain. The occurrence of bradypnea and changes in breathing remained constant.

Considering the parameter for pain, 12 patients remained with this complication since they arrived in the PACU until the 60th minute of permanence in this room.

Table 3. Frequency distribution of complications presented by the patients. Belo Horizonte, 2015.

\begin{tabular}{|c|c|c|c|c|c|c|c|}
\hline \multirow[t]{2}{*}{ Variables } & & 0 & 15 & 30 & 45 & 60 & Média \\
\hline & & $\mathrm{N}(\%)$ & $\mathrm{N}(\%)$ & $\mathrm{N}(\%)$ & $\mathrm{N}(\%)$ & $\mathrm{N}(\%)$ & $\mathrm{N}(\%)$ \\
\hline $\begin{array}{l}\text { Arterial } \\
\text { hypotension }\end{array}$ & & $2(8.3)$ & $2(8.3)$ & $2(8.3)$ & $3(12.5)$ & $3(12.5)$ & $2.4(10.0)$ \\
\hline $\begin{array}{l}\text { Arterial } \\
\text { hypertension }\end{array}$ & & $2(8.3)$ & $0(0.0)$ & $0(0.0)$ & $0(0.0)$ & $0(0.0)$ & $0.4(1.7)$ \\
\hline Bradycardia & & $1(4.2)$ & $1(4.2)$ & $2(8.3)$ & $2(8.3)$ & $2(8.3)$ & $1.6(6.7)$ \\
\hline Tachycardia & & $6(25.0)$ & $6(25.0)$ & $2(8.3)$ & $2(8.3)$ & $2(8.3)$ & $3.6(15.0)$ \\
\hline Hypothermia & & $9(37.5)$ & $7(29.2)$ & $4(16.7)$ & $3(12.5)$ & $3(12.5)$ & $5.2(21.7)$ \\
\hline Bradypnea & & $1(4.2)$ & $1(4.2)$ & $1(4.2)$ & $1(4.2)$ & $1(4.2)$ & $1.0(4.2)$ \\
\hline Anxiety & & $0(0.0)$ & $0(0.0)$ & $4(16.7)$ & $3(12.5)$ & $3(12.5)$ & $2(8.3)$ \\
\hline Pain & & $12(50.0)$ & $13(54.2)$ & $12(50.0)$ & $13(54.2)$ & $13(54.2)$ & $12.6(52.5)$ \\
\hline $\begin{array}{l}\text { Alteration } \\
\text { consciousness }\end{array}$ & of & $10(41.7)$ & $6(25.0)$ & $3(12.5)$ & $3(12.5)$ & $2(8.3)$ & $4.8(20.0)$ \\
\hline Hypoxemia & & $14(58.3)$ & $14(58.3)$ & $12(50.0)$ & $8(33.3)$ & $8(33.3)$ & $11.2(46.7)$ \\
\hline $\begin{array}{l}\text { Changes } \\
\text { breathing }\end{array}$ & in & $3(12.50)$ & $4(16.66)$ & $3(12.50)$ & $3(12.50)$ & $3(12.50)$ & $3.2(13.33)$ \\
\hline
\end{tabular}




\section{DISCUSSION}

The complications most frequently presented by the patients when in PACU were pain, hypoxemia, hypothermia, and alterations of consciousness, in this following sequence. In addition to these complications, there were identified alterations of arterial hypotension, arterial hypertension, bradycardia, tachycardia, bradypnea, anxiety, and changes in breathing.

All these complications were verified by the application of Aldrete - Kroulik index, patient reporting, and signs analyzed by the researcher during the application of the questionnaire.

Pain was the most common complication, yielding a mean of $52.5 \%$ patients showing this complication in the first 60 minutes of permanence in the PACU.

According to the text, pain is one of the most frequent complications in patients during the period of anesthetic recovery, and it should be treated promptly. (DE MATTIA; SILVA; ARANTES, 2008; MENDONZA; PENICHE, 2008). The prevention of this complication is essential to improve the anesthetic-surgical results, once its control can decrease the pain associated with the surgical incision, and may prevent the development of other complications, such as tachycardia, anxiety, and arterial hypertension. Also, controlling pain is effective to reduce the hospital length of stay. (CAPELLO et al., 2009; DE MATTIA et al., 2010).

The second most common complication at the first hour of the patient permanence in the PACU was hypoxemia. This complication was observed from the application of the Aldrete Kroulik index, which gives a score one (1) for patients with $\mathrm{SpO}_{2}>90 \%$, even those receiving supplemental oxygen. (SOBECC, 2013).

Hypoxia can be associated as a consequence of the residual effects of anesthetics, specifically due to the use of opioids that can cause depression of the respiratory system. (POPOV; PENICHE, 2009).

The American Society of PeriAnesthesia Nurses (ASPAN) recommends that in the admission of the patient in the PACU, the respiratory airway is a parameter that should be observed with priority. According to this association, administering humidified oxygen helps to eliminating the anesthetic agents and preventing hypoxia. (ASPAN, 2012)

The third most frequent complication was hypothermia, with a mean of $21.7 \%$ patients. This complication is defined as a body temperature below than $36^{\circ}$ C. (POVEDA; GALVÃO, 2011; CASTRO et al., 2012)

Among the factors that may contribute to the development of hypothermia, the most common in post-surgical patients included: Temperature of the operatory room, infusion of cold solutions in body cavities or intravenously, patient's age, muscle relaxation, exposure of body cavities, length of time for the surgery, type of surgery, and ventilation without heated gases. (GALVÃO, 2011; CASTRO et al., 2012; POVEDA; DE MATTIA et al., 2013)

It is extremely important that the health team involved with patient's care during the anesthetic recovery period prevent these complications. It is especially important for the nursing team, once these complications can contribute to increase the occurrence of alterations such as cardiac morbidity, arrhythmias, elevation of catecholamine, hormonal changes, coagulopathies, increasing the surgical site infection, as well as prolonging the length of time for the patient's recovery that may extend even after the patient discharge from the PACU. (DE MATTIA et al., 2010; POVEDA; GALVÃO, 2011; CASTRO et al., 2012)

Thus, planning actions to control these complications should be performed throughout the perioperative period.

Another very common complication during the first hour of the patient's permanence in the PACU is the alteration of consciousness. Drowsy and confused patients, who were aroused only when requested by the researcher, received score one (1), according to the Aldrete - Kroulik index. (SOBECC, 2013). This complication is mainly related to the residual effect of the anesthetics, hypoxia, pain or anxiety. (MORAES; PENICHE, 2003; MENDONZA et al., 2010; NUNES; MATOS; DE MATTIA, 2014).

Tachycardia, which is the HR more than 100 BPM, was verified in a mean of $15 \%$ of the patients, and the bradycardia, which is the HR below than 60 BPM, was observed in $6.7 \%$ of the patients. Both of these complications have correlation with the presence of pain, hypoxemia, hypothermia, and increase in body temperature and anxiety. (CHATTEFUEE; HADI, 2006; GALDEANO; ROSSI; PENICHE, 2007; POPOV; PENICHE, 2009)

The changes in the arterial blood pressure were analyzed using the circulatory parameter of Aldrete - Kroulik index. It is assigned score one (1) when the blood pressure has $20 \%$ to $49 \%$ of difference from the preanesthetic period. (CHATTEFUEE; HADI, 2006). A mean of $10 \%$ 
The association between complications...

and $1.66 \%$ of patients had present signs of hypotension and hypertension, respectively.

The increasing and decreasing in $20 \%$ of the basal blood pressure values was characterized as the hypertension and hypotension arterial, respectively. Among the factors that contribute to the arterial hypertension in the PACU, we can emphasize those associated to the condition of arterial hypertension previously diagnosed, as well as factors related to pain, fear, deep breathing, curative, and drugs interaction. (GALDEANO; ROSSI; PENICHE, 2007)

Bradypnea was observed in one (1) patient. It is characterized as the numbers of respiratory incursions below than 12 in 60 seconds. This complication is related to the residual effects of the anesthetics, presence of pain, and fear, associated to the deep breathing due to the pain and hypothermia, which can generate complications as hypoventilation and hypoxemia. (POPOV; PENICHE, 2009; BARROS, 2010; MENDONZA et al., 2010; NUNES; MATOS; DE MATTIA, 2014).

Anxiety was observed in a mean of $8.3 \%$ of patients, and it can be linked to the previous factors of the surgical procedure, physiopathological process, and other complications, such as pain and tachycardia. In this last hypothesis, pain and tachycardia may be the cause or result of the anxiety (CAPELLO et al., 2009; POPOV; PENICHE, 2009; NUNES; MATOS; DE MATTIA, 2014)

Changes in breathing were verified using the Aldrete - Kroulik index, where it attributed score one (1) for the patient who presented dyspnea or some respiratory limitation. This complication may be associated to bradypnea, tachycardia, pain, and anxiety, and may lead to hypoxemia and alteration in level of consciousness. (NUNES; MATOS; DE MATTIA, 2014)

Comparing the results obtained in this study with the results from the first study (with 42 patients), it showed that independently whether the patient had or did not have some comorbidity or mild physiological problem, which led to the surgical procedure, the triad of pain, hypoxia and hypothermia, showed as the most frequent during the first 60 minutes of patient's permanence in the PACU. (NUNES; MATOS; DE MATTIA, 2014)

It is worth noting that pain, hypothermia, and hypoxemia remained present in some patients even after 60 minutes of permanence in the PACU.

Thus, the nurse's actions in the PACU are extremely important. Once recognizing and identifying the complications presented by the patients, especially the most common complications, it is necessary to make immediate nursing interventions in order to prevent the development of other complications, as well as reduce the patient's discomfort and the length of time of permanence in the PACU. (CUNHA; PENICHE, 2007; DE MATTIA et al., 2010; NUNES; MATOS; DE MATTIA, 2014)

This study also showed that, although present in the scientific text, the concordance between the most frequent complications (pain, hypoxemia, hypothermia, and alteration of consciousness) and presence of pre-established physiological conditions were not statistically significant after the questionnaires were analyzed manually. Therefore, further research to regarding this subject is recommended, using a larger sample, in order to clarify this possible association.

\section{CONCLUSION}

It concludes that the alterations presented by the patients during the anesthetic recovery period were hypotension and arterial hypertension, bradycardia, and tachycardia, hypothermia, bradypnea, anxiety, pain, alterations of consciousness, hypoxemia, and changes in breathing.

Among the complications analyzed, some of them presented a decrease over the 60 minutes of patient permanence in the PACU, such as arterial hypertension, tachycardia, hypothermia, alterations of consciousness, and hypoxemia.

It observed that $12(50 \%)$ patients who presented pain remained with this complication since they arrived in the PACU and after the first hour of anesthetic recovery period. Therefore, it is suggested that the nursing staff should promptly treat this complication, once it has potential to develop other complications and increase the length of permanence in the PACU and hospitalization (DE MATTIA; SILVA; ARANTES, 2008; CAPELLO et al., 2009).

Considering the prevalence of the most frequent complications, the study showed that there were no differences between patients without comorbidities or those who presented dysfunctions due to the surgical procedure and the patients who already had some mild systemic change. It was verified that for both studies, the triad composed of pain, hypoxemia and hypothermia were the most incident alteration in the PACU.

It suggests the development of more studies, with a larger sample, covering patients without comorbidities or who just have alterations that were the cause that lead to the surgical procedure, in order to elucidate the correlation presented by the 
in this study.

RESUMO: verificar a relação entre as condições fisiológicas de base do paciente no pré-operatório com a ocorrência de complicações no paciente em período de recuperação anestésica. pesquisa quantitativa, com delineamento não experimental, comparativa, de campo e prospectiva. Amostra foi constituída por 24 adultos, submetidos à cirurgia eletiva, com anestesia geral, apresentando classificação da American Society Anesthesiologists (ASA) I ou II; e que não possuíam as comorbidades elencadas para o estudo. As complicações mais freqüentes: dor, hipoxemia, hipotermia e alterações da consciência. Na avaliação manual dos questionários não foi verificada concomitância significativa entre as manifestações mais freqüentes. Sugere-se o desenvolvimento de mais estudos a respeito das complicações apresentadas por pacientes sem comorbidades no período de recuperação anestésica.

PALAVRAS-CHAVE: Enfermagem Perioperatória; Período Pré-Operatório; Sala de Recuperação; Complicações Pós-Operatórias

\section{REFERENCES}

AMERICAN SOCIETY OF PERIANESTHESIA NURSES - ASPAN. Perianesthesianursing standarts, practice recommendations and interpretative statements. Cherry Hill: ASPAN, 2012.

ASSOCIAÇÃO BRASILEIRA DE ENFERMEIROS DE CENTRO CIRÚRGICO, RECUPERAÇÃO ANESTÉSICA E CENTRO DE MATERIAL E ESTERILIZAÇÃO. Práticas Recomendadas da SOBECC. 6. ed. São Paulo: SOBECC, 2013.

BARROS, A. L. B. L. Anamnese e exame físico: avaliação diagnóstica de enfermagem no adulto. 2. ed. Porto Alegre: Artmed, 2010.

BRASIL. Ministério da Saúde. Portaria n.1.884 de 11 de novembro de 1994. Normas para projetos físicos de estabelecimentos assistenciais de saúde. Brasília (DF): Ministério da Saúde, 1994.

CASTRO, F. S. F. et al.(citar todos os autores) Temperatura corporal, índice Aldrete e Kroulik e alta do paciente da Unidade de Recuperação Pós-Anestésica. Rev Esc Enferm USP, São Paulo, v. 46, n. 4, p. 872-876, 2012. http://dx.doi.org/10.1590/S0080-62342012000400013

CAPELLO, R. G. et al.(citar todos os autores). Intervenções de enfermagem na recuperação anestésica: controle da dor, náuseas, hipotermia e outras complicações do pós-operatório. Rev Dor, São Paulo, v. 10, n. 2 , p. 113-119, 2009.

CHATTEFUEE, S.; HADI, A. S. Regression analysis by example. New Jersey: John Wiley \& Sons, 2006. http://dx.doi.org/10.1002/0470055464

CUNHA, A. L. S. M.; PENICHE, A. C. G. Validação de um instrumento de registro para sala de recuperação pós-anestésica. Acta Paul Enferm., São Paulo, v. 20, n. 2, p. 151-160, 2007.

DE MATTIA, A. L. e et al.(citar todos os autores). Diagnósticos de enfermagem nas complicações em sala de recuperação anestésica. Enfermería Global, Murcia, v. 9, n. 18, p. 1-11, 2010.

DE MATTIA, A. L.; et al.(citar todos os autores). Infusão venosa aquecida no controle da hipotermia no período intraoperatório. Rev Latino-Am Enferm., Riberão Preto, v. 21, n. 3, p. 801-810, 2013.

DE MATTIA, A. L.; SILVA, A. G.; ARANTES, S. G. Atuação do enfermeiro no controle da dor em recuperação anestésica. Rev SOBECC, São Paulo, v. 13, n. 3, p. 27-32, 2008. 
GALDEANO, L. E.; ROSSI, L. A.; PENICHE, A. C. G. Assistência de enfermagem na recuperação pósanestésica. In: CARVALHO, R.; BIANCHI, E. R. F. Enfermagem em centro cirúrgico e recuperação. Barueri: Manole, 2007. p. 267-298.

MENDONZA, I. Y. Q. et al.(citar todos os autores). Retrospectiva histórica das salas de recuperação pósanestésica em enfermagem. Temperamentvm, Madrid, v. 11, 2010. Disponível em: <http://www.index f.com/temperamentum/tn11/t7186.php>. Acesso em 22/10/2014.

MENDONZA, I. Y. Q.; PENICHE, A. C. G. Complicações do paciente cirúrgico idoso no período de recuperação pós-anestésica: revisão de literatura. Rev SOBECC, São Paulo, v. 13, n. 1, p. 25-31, 2008.

MORAES, L. O.; PENICHE, A. C. Assistência de enfermagem no período de recuperação anestésica: revisão de literatura. Rev Esc Enferm USP, São Paulo, v. 37, n. 4, p. 34-42, 2003. http://dx.doi.org/10.1590/S008062342003000400004

NUNES, F. C.; MATOS, S. S.; DE MATTIA, A. L. Análise das complicações em pacientes no período de recuperação anestésica. Rev SOBECC, São Paulo, v. 19, n. 3, p. 129-135, 2014.

http://dx.doi.org/10.4322/sobecc.2014.020

OLIVEIRA FILHO, G. R. Rotinas de cuidados pós-anestésicos de anestesiologistas brasileiros. Rev Bras Anestesiol., Rio de Janeiro, v. 53, n. 4, p. 518-534, 2003.

POPOV, D. C.; PENICHE, A. C. As intervenções do enfermeiro e as complicações em sala de recuperação pós-anestésica. Rev Esc Enferm USP, São Paulo, v. 43, n. 4, p. 953-961, 2009.

http://dx.doi.org/10.1590/S0080-62342009000400030

POTTER, P. A.; PERRY, A. G. Fundamentos de enfermagem. 6. ed. Rio de Janeiro: Elsevier, 2005.

POVEDA, V. B.; GALVÃO, C. M. Hipotermia no período intra-operatório: é possível evitá-la? Rev Esc

Enferm USP, São Paulo, v. 45, n. 2, p. 411-417, 2011. http://dx.doi.org/10.1590/S0080-62342011000200016 